\title{
6.3 Formation of prospective teacher professional motivation in the development of the new Ukrainian school
}

The conceptual principles of implementing the state policy in the field of reforming secondary education "the new Ukrainian School" approved in 2016, reveals the strategic ways to reform Ukrainian secondary schools until 2029.

Among the nine key components required for the new school, the second position relates to a highly motivated teacher, who must be competitive, constantly working on their improvement, responsible, able to respond and adapt quickly to ongoing changes in the informational world, open and creative to perceive new ideas and ready to put them into practice and, what is more important, - capable of steady development of their soft and professional skills. "The Ukrainian school will be successful if it is joined by successful teachers. They - successful teachers and professionals - will resolve a multitude of issues regarding the quality of teaching, the volume of home assignments, communication with children and school administration. Children need a leader who can lead them forward, who likes their discipline, who teaches them professionally", says in Conceptual Principles of Secondary School Reform "The New Ukrainian School”

Obviously, it is a teacher who is motivated to pedagogical professionalism. That's why there is an urgent need to form strong incentives for professional motivation in prospective teachers who are able to become a true "agent of change" and change the third millennium school for the better.

The aim of this paper is to analyze the key incentives necessary to form the prospective teacher professional motivation in the development of the new Ukrainian school; reveal dominating incentives (extrinsic/intrinsic) in their professional motivation; consider the conditions necessary for developing sustainable incentives for the students' professional education.

While researching we have taken into account various scientific resources. Among the scholars who have investigated the problem of student motivation is (Georgiev, 2018); who has performed the motivational analysis in professional 
competences of prospective military officers (Luzan \& Zaitseva, 2013); has studied the students' cognitive activity in higher education institutions of economic sciences; S. Ihnatenko has investigated the development of students' motivation for their out-ofclass physical training (Ihnatenko, 2016); T. Klybanivska has analyzed the motivation as a determinant of students' educational activity in higher education institutions (Klybanivska, 2015); G. Kostyshyna has studied students' learning and cognitive activities in technical institutions (Kostyshyna, 2003); Luzan P. has considered students' academic activity in agricultural universities (Luzan, 2015); Patyk Yu. has researched future social workers motivational tendencies (Patyk, 2016); Silveistr A., Mokliuk M. have investigated the motivation in students' education as psychological and pedagogical problems (Silveistr \& Mokliuk, 2014); Y. Serbin has analyzed the personal adaptive potential of liberal arts students in the process of their adaptation to learning (Serbin, 2018).

Various aspects of forming strong motivation for learning activities, professional education, creative competency have been outlined by the following Ukrainian researchers: I. Halian (Halian, 2018), Y. Kaliuzhna (Kaliuzhna, 2016), A. Melnyk (Melnyk, 2017), L. Peretiatko (Peretiatko, 2016), V. Fritsiuk (Fritsiuk, 2016), V. Chernii (Chernii, 2017), S. Yalanska (Yalanska, 2017) and others.

Lynley H. Anderman, Valerie S. Leake have provided profound insights into the theory on motivation. Their findings cover three fundamental human needs - need for a sense of autonomy, need for fitting in, need for competence (Anderman \& Leake, 2005); Hamizan N., Zaid N. M. have investigated the enhancement of students motivation in learning through Blossoms video activity (Hamizan \& Zaid, 2014); Chan H., Wang X. have analyzed the connection between motivation for learning and learning outcomes between the students of technical colleges (Chan \& Wang, 2016);

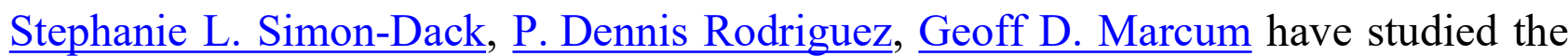
habits, motives, and strategies of college students with symptoms of ADHD (SimonDack, Rodriguez \& Marcum, 2016); Bruce W. Tuckman have revealed the links between motivational factors and self-regulatory behavior of college students (Tuckman, 2003); Stukalina Y. has described the specific features of modeling 
satisfaction and motivation of university students in integrated educational environment (Stukalina, 2016); Charikova I., Zhadanov V. have highlighted the role of a teacher in training a highly-qualified individual with intellectual, moral and spiritual values in a new paradigm of university education (Charikova \& Zhadanov, 2017); Plugina M. I., Sokolova I. Y., Gorbunkov V. Y., Znamenskaya S. V., Goman M. V. have outlined the role of innovative educational technologies (communicative, interactive, searching, informational, stimulant, entertaining, and others) in developing motivation for studying (Plugina, Sokolova, Gorbunkov, Znamenskaya \& Goman, 2016); Schlag B. has analyzed the links between studying and motivation (Schlag, 2013); Wagner R., Hinz A., Rausch A., Becker B. have specified the interrelation between learning and motivation (Wagner, Hinz, Rausch \& Becker, 2009); Öqvist A., Malmström M. have studied the influence of teacher leadership on the effectiveness of students' learning (Öqvist \& Malmström, 2018).

The overview of above-mentioned resources has proved that the problem of studying student incentives and motivation is relevant not only in Ukraine but internationally. The educators study its various aspects: both theoreticalmethodological and practice-oriented. Taking into account the educational reforms that have been implemented in Ukraine recently, we are to focus on studying the problem of forming prospective teacher motivation.

Nowadays, there is no unambiguous interpretation of the concept of "motivation". In this article, we use the definition given by of S. Rubinstein, who understands motivation as more or less adequately conscious incentives. (Rubinstein, 2002: 542). Consequently, the motivation can be defined as one of the most important components of the psychological structure of any activity, and which reveals the incentive nature of any action, behavior, human activity, and its essence. In learning, such motivation implies the incentives of initial cognitive activity, which is essential for ensuring its effectiveness. If a student learns without some cognitive interest, their motivation is to get a diploma, please their parents, or something else, and therefore, his knowledge might not be profound, which might result in having a non-motivated and indifferent teacher. 
Thus, under the motivations for the educational activity we understand the factors that impel a person to this activity, and determine human cognitive activity i.e. their ideas, goals, needs, interests, beliefs, social attitudes, feelings, etc. Student professional motivation emerges/develops in higher education institutions because the educational activity is closely connected with the professional and pedagogical activity. Therefore it is essential to talk about the motivations of the students' professional activity. By the latter, we mean everything that stimulates and directs them to study future disciplines.

The methods used in the research and full description of the experiment. Empirical study was conducted in Poltava V.G. Korolenko National Pedagogical University in March 2020. Second-year students (aged 18-19) of the Faculty of Philology and Journalism (full-time department) were selected to participate in a survey.

The research uses the following methodologies: 1) "Motivation for studying in pedagogical universities" (S.A Pakulina, S.M Ketko) (Ketko, Pakulina, 2011); 2) "Studying motivation for students' educational activity" (modification by A.A.Rean, V.A Yakunin)" (Methods for studying motivation of educational activity (modification by A.A Rean, V.A Yakunin, 2004).

Methods of studying students' motivations in pedagogical universities (S.A Pakulina, S.M.Ketko) offer students to fill in a table which divided into three blocks of motivations: 1) motivation to apply to university; 2) motivation to study at university; 3) professional motivation.

\begin{tabular}{|l|l|}
\hline \multicolumn{1}{|c|}{ Motivations } & Points \\
\hline \multicolumn{1}{|c|}{ I. What motivated you to choose this particular profession? } \\
\hline 1. Free education, low tuition fees & \\
\hline 2. Specialized secondary education & \\
\hline 3. Desire to obtain higher education & \\
\hline 4. Family tradition, parents wishes & \\
\hline 5. Friend's advice & \\
\hline 6. Higher education institution / faculty image and credibility & \\
\hline 7. Interest in teaching career & \\
\hline
\end{tabular}




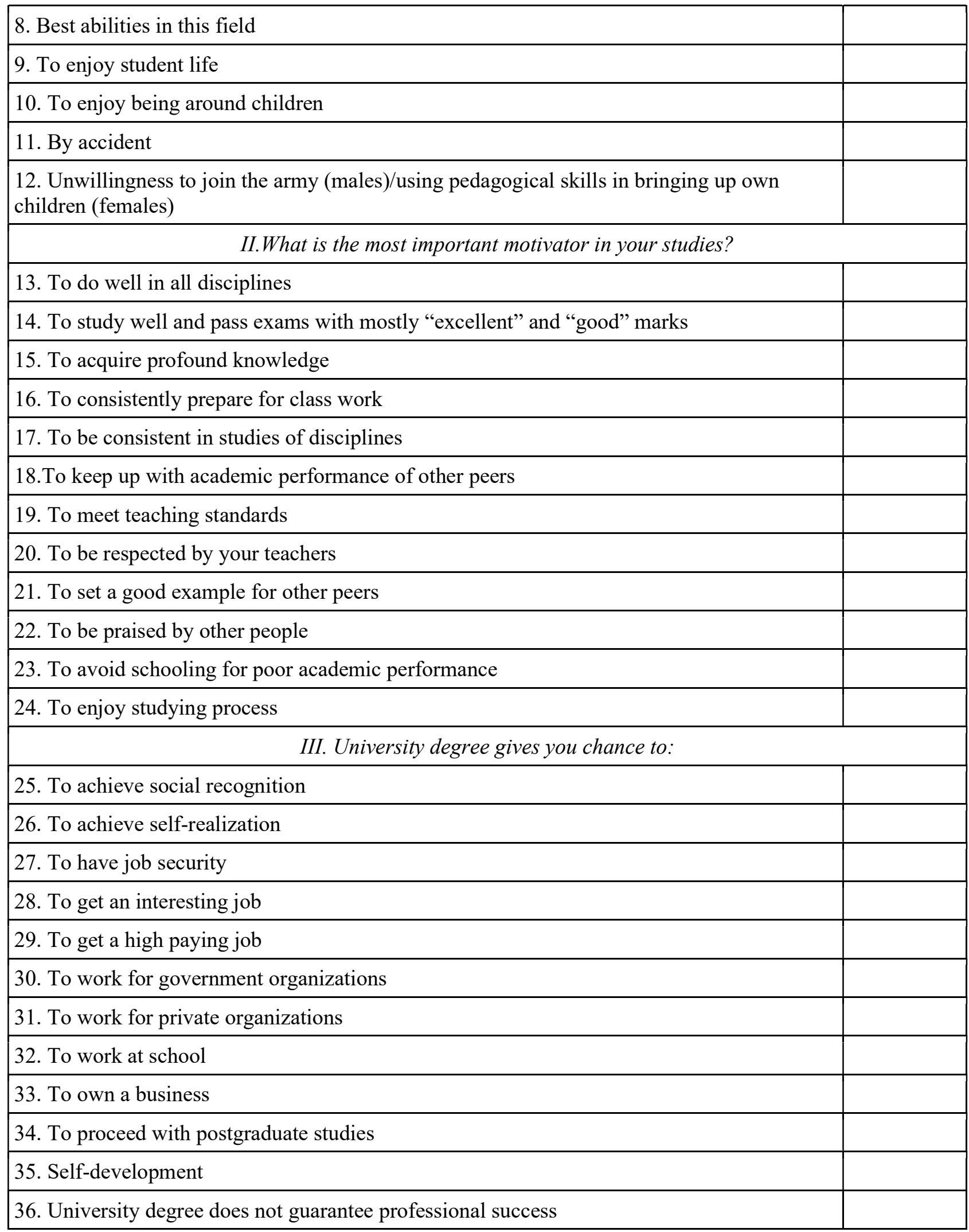

Students have to select the most important motivations to study in pedagogical university on a scale: 5 points - very significant, 3-4 - significant, 0-2 - not significant. Survey results analysis is given below.

The methodology for studying the motivation for studying activities (modification by A.A.Rean, V.A.Yakunin) was carried out in accordance with the first 
version, when students were given a list of motivations (the total number - 16), and they had to choose five most significant and tick them.

\section{List of motivations}

1. To be a high-qualified specialist

2. To get a university degree

3. To do well in all disciplines

4. To study well and pass exams with mostly "excellent" and "good" marks

5. To get a scholarship

6. To acquire profound knowledge

7. To be prepared for class work

8. To be consistent in studies of disciplines

9. To keep up with academic performance of your peers

10. To acquire the skills for successful career

11. To meet teaching standards

12. To be respected by teachers

13..To set a good example for other peers

14. To be praised by parents and other people

15. To avoid schooling for poor academic performance

16. To enjoy studying process

The survey results (Form 1) defined the frequency of motivations from among the most significant in this survey. On the basis of this, the rank of each motivation in the corresponding sample was determined.

\begin{tabular}{|l|}
\hline Motivation № in the list \\
\hline Quantity of motivations \\
\hline Frequency of the motivation \\
\hline Motivation rank \\
\hline
\end{tabular}

As mentioned above, there is no unambiguous concept of "motivation". In this article we use the definition given by of S. Rubinstein, who understands motivation as more or less adequately conscious incentive. (Rubinstein, 2002: 542). We consider motivation to be one of the most important components of psychological structure of 
any activity by means of which the motivation behind person's actions, their behavior and essence is revealed. In educational activity such incentives could be the motivation for educational and cognitive activity. Disclosing them is essential for ensuring their efficiency. If a student learns without cognitive interest, and his motivation is only to get a university degree or to please his/her parents or something else, he/she will never get profound knowledge. As a result - he/she will not become a motivated and interesting teacher.

Thus, under the motivation for educational activity we understand the factors that impel person to this activity, and determine human cognitive activity i.e. their ideals, goals, needs, interests, beliefs, social attitudes, feelings, etc. It is essential to talk about motivation of the student education activity because it is closely connected with professional and pedagogical activity and student motivation appears/develops in higher education institutions. By the latter we mean everything that stimulates and directs them to study disciplines.

The professional motivation for pedagogical university education activity implies the system of incentives that determines the specific student activities or behavior. These incentives may be extrinsic, outside the student's academic activity and having no direct connection with studying ("just to obtain knowledge" without any intentions to work in school, to keep up with fellow students, avoid schooling for poor academic performance, to get a scholarship, etc.), and intrinsic ones which are essential for the process of learning. They are strongly associated with studying professional skills (to develop their personality, cognitive interests, to pursue profound knowledge, to seek self-realization and professional development, etc.).

Results of methodology "Motivations for studying at pedagogical universities" (S.A. Pakulina, S.M.Ketko) are shown in tables 1,2,3; description of the methods on pages 6,7 of this article 
Table 1. Survey results on methodology "Motivations to study in pedagogical universities" (S.A. Pakulina, S.M. Ketko) (The first block of questions "What motivated you to choose this particular profession?"

\begin{tabular}{|l|l|l|l|l|l|l|l|l|l|l|l|l|l|l|l|}
\hline $\begin{array}{l}\text { No } \\
\text { ation }\end{array}$ & 1 & 2 & 3 & 4 & 5 & 6 & 7 & 8 & 9 & 10 & 11 & 12 & $\begin{array}{l}\text { Intrinsi } \\
\mathrm{c} \\
\text { motiva } \\
\text { tion } \\
\text { total } \\
\text { points } \\
\mathrm{c} \\
\text { motivat } \\
\text { ion total } \\
\text { points } \\
\text { by a } \\
\text { factor } \\
\text { of } 1.25\end{array}$ & $\begin{array}{l}\text { Extrin } \\
\text { sic } \\
\text { motiva } \\
\text { tion } \\
\text { total } \\
\text { points }\end{array}$ \\
\hline $\begin{array}{l}\text { Motiv } \\
\text { ation } \\
\text { total } \\
\text { points }\end{array}$ & 5 & 88 & $\begin{array}{l}25 \\
7\end{array}$ & 87 & 40 & 10 & 216 & 21 & 119 & 180 & 76 & 19 & 952 & $\mathbf{1 1 9 0}$ & $\mathbf{8 1 8}$ \\
\hline $\begin{array}{l}\text { Motiv } \\
\text { ation } \\
\text { rank }\end{array}$ & 4 & 9 & 1 & 10 & 12 & 8 & 2 & 3 & 7 & 6 & 11 & 5 & & & \\
\hline
\end{tabular}

Table 2. Survey results on methodology "Motivations for studying in pedagogical universities" S.A. Pakulina, S.M. Ketko) (The second block of questions "What is the most important thing in your studies?"

\begin{tabular}{|c|c|c|c|c|c|c|c|c|c|c|c|c|c|c|c|}
\hline $\begin{array}{l}\text { № } \\
\text { Motiv } \\
\text { ation }\end{array}$ & 13 & 14 & 15 & 16 & 17 & 18 & 19 & 20 & 21 & 22 & 23 & 24 & $\begin{array}{l}\text { Intrinsic } \\
\text { motivati } \\
\text { on total } \\
\text { points }\end{array}$ & $\begin{array}{l}\text { Intrinsic } \\
\text { motivati } \\
\text { on total } \\
\text { points } \\
\text { by a } \\
\text { factor of } \\
125\end{array}$ & $\begin{array}{l}\text { Extrin } \\
\text { sic } \\
\text { motiva } \\
\text { tion } \\
\text { total } \\
\text { points }\end{array}$ \\
\hline $\begin{array}{l}\text { Motiv } \\
\text { ation } \\
\text { total } \\
\text { points }\end{array}$ & $\begin{array}{l}20 \\
4\end{array}$ & $\begin{array}{l}22 \\
8\end{array}$ & $\begin{array}{l}24 \\
8\end{array}$ & $\begin{array}{l}18 \\
6\end{array}$ & $\begin{array}{l}20 \\
2\end{array}$ & $\begin{array}{l}18 \\
3\end{array}$ & 199 & $\begin{array}{l}19 \\
3\end{array}$ & $\begin{array}{l}15 \\
9\end{array}$ & $\begin{array}{l}15 \\
6\end{array}$ & $\begin{array}{l}11 \\
7\end{array}$ & $\begin{array}{l}21 \\
5\end{array}$ & 1081 & 1351 & 1209 \\
\hline $\begin{array}{l}\text { Motiv } \\
\text { ation } \\
\text { rank }\end{array}$ & 4 & 2 & 1 & 8 & 5 & 9 & 6 & 7 & 10 & 11 & 12 & 3 & & & \\
\hline
\end{tabular}

Table 3. Survey results on methodology "Motivations for studying in pedagogical universities" S.A. Pakulina, S.M. Ketko) (The third block of questions "University degree gives you a chance to..."

\begin{tabular}{|c|c|c|c|c|c|c|c|c|c|c|c|c|c|c|c|}
\hline $\begin{array}{l}\text { № } \\
\text { Motiv } \\
\text { ation }\end{array}$ & 25 & 26 & 27 & 28 & 29 & 30 & 31 & 32 & 33 & 34 & 35 & 36 & $\begin{array}{l}\text { Intrinsic } \\
\text { motivati } \\
\text { on total } \\
\text { points }\end{array}$ & $\begin{array}{l}\text { Intrins } \\
\text { ic } \\
\text { motiva } \\
\text { tion } \\
\text { total } \\
\text { points } \\
\text { by a } \\
\text { factor } \\
\text { of } 1.25\end{array}$ & $\begin{array}{l}\text { Extrinsi } \\
\text { c } \\
\text { motivati } \\
\text { on total } \\
\text { points }\end{array}$ \\
\hline $\begin{array}{l}\text { Motiv } \\
\text { ation } \\
\text { total } \\
\text { points }\end{array}$ & $\begin{array}{l}17 \\
9\end{array}$ & $\begin{array}{l}24 \\
9\end{array}$ & $\begin{array}{l}21 \\
8\end{array}$ & $\begin{array}{l}23 \\
4\end{array}$ & $\begin{array}{l}23 \\
1\end{array}$ & $\begin{array}{l}15 \\
9\end{array}$ & 200 & $\begin{array}{l}17 \\
2\end{array}$ & $\begin{array}{l}18 \\
1\end{array}$ & $\begin{array}{l}11 \\
7\end{array}$ & $\begin{array}{l}23 \\
0\end{array}$ & 87 & 986 & 1233 & 1271 \\
\hline $\begin{array}{l}\text { Motiv } \\
\text { ation } \\
\text { rank }\end{array}$ & 8 & 1 & 5 & 2 & 3 & 10 & 6 & 9 & 7 & 11 & 4 & 12 & & & \\
\hline
\end{tabular}


Results show that intrinsic motivations turn out to be dominant for students in their studies. According to the first block of questions "What motivated you to choose this particular profession?" the ratio of intrinsic/extrinsic motivations is $1190 / 818$ (Table 1) and is equal to 1.455; in the second block of the questions "What is the most important thing in your studies?" the intrinsic / extrinsic motivation ratio is 1351/1209 (Table 2) and is equal to 1,117; in the third block of questions "University degree gives you a chance to..." intrinsic / extrinsic motivation ratio is 1233/1271 (Table 3) and is equal to 0.969 . Fig. 1 shows that overall ratio of internal / external motivations is $3774 / 3298$ respectively, and equals 1.144 .

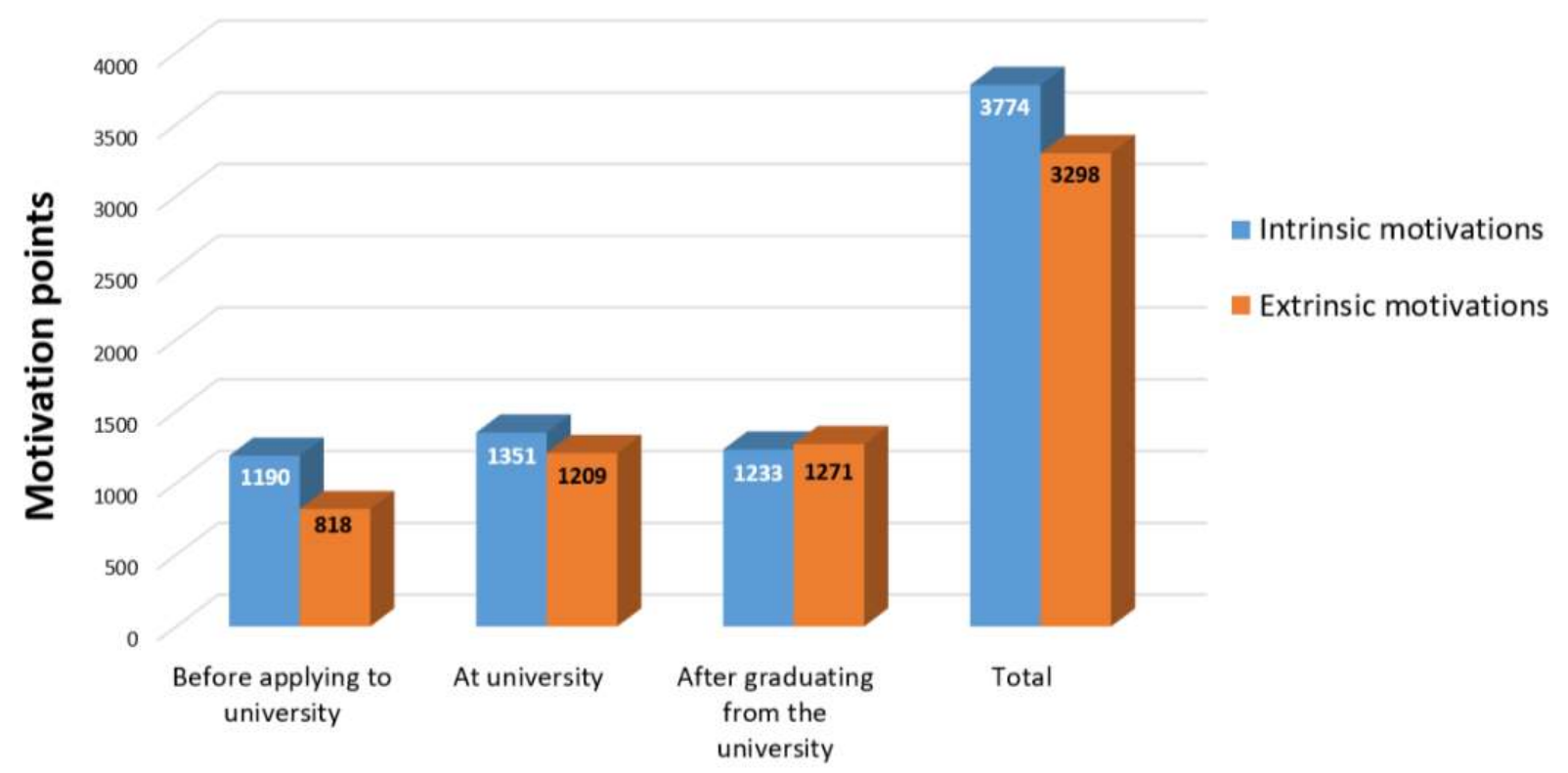

Motivation Periods

Figure 1.The overall ratio of intrinsic (by factor of 1.25) / extrinsic motivation based on the methodology "Motivations to study in pedagogical universities" (S.A.Pakulina, S.M.Ketko)

Survey results on individual motivations prove the key motivations that contribute to the choice of teaching career (first block of questions, page 6) are: first place - desire to obtain high education(257 points); second place - interest in teaching career(216 points); third place - great abilities in this field (211 points) (Table 1). The main reasons for learning (second block of questions, page 7) are: first place - to acquire profound knowledge (248 points); second place - to do well in studies and examinations, mostly "excellent" and "good" marks (228 points); third place - to enjoy 
studying process (215 points) (Table 2). The third block of questions "University degree gives you a chance to..." (page 7) results in the following: first place - to achieve self-realization (249 points); second place - get an interesting job (234 points); third place - to get a high paying job (231 points).

Thus, the main motivations for studying at pedagogical university were intrinsic ones (total points 3774). Students with intrinsic motivations have broad cognitive incentives, urge for self-education. They adapt effectively to university education, strive for improving the studying process, its content and organization, require nontraditional forms and methods of teaching, non-standard presentation of the material, highly qualified teachers who are always ready to cooperate. Extrinsic motivations to teach students (total points-3298) are characterized by low cognitive incentives, poor adaptation to education in university, weak creativity and the like.

The survey results on the motivations for studying activities (a modification by A.A. Rean, V.A. Yakunina) (description of methods is presented on pp. 7, 8) are summarized in Table 4. And according to the results first place is "to acquire skills for successful career" (83,64\%, 46 students); second place -"to be a highly-qualified specialist" (74,55\%, 41 students); third place - "to get a university degree" $(67,27 \%$, 37 students); forth place - "to acquire profound knowledge" (61,82\%, 34 students); fifth place - "to enjoy studying process" (49,09\%, 27 students).

Table 4. Results on methodology "Studying motivations for student learning activities" (modification by A.A. Rean and V.A. Yakunina)

\begin{tabular}{|l|l|l|l|l|l|}
\hline Motivation rank & 1 & 2 & 3 & 4 & 5 \\
\hline Quantity of motivation & 46 & 41 & 37 & 34 & 27 \\
\hline Motivation frequency \% & 83.64 & 74.55 & 67.27 & 61.82 & 49.09 \\
\hline Motivation № & 10 & 1 & 2 & 6 & 16 \\
\hline
\end{tabular}

Research results confirm that effectiveness and success of developing students' professional motivation depends on the maturity of their incentives. Intrinsic, professionally oriented motivations (high cognitive interest) should dominate the extrinsic ones (low cognitive interest). In order to achieve these results higher 
education institutions should organize purposeful, systematic work based on partnership and subject-to-subject interaction among the participants of studying process.

We found out that the following conditions are required for development of sustainable motivations for student professional activity:

$\checkmark$ procedural and informative: facilitation of educational activities; introduction of personally oriented learning; individualization of educational and professional activities; adhering to correct correlation of theoretical knowledge and practical skills; a variety of forms of individual and group work during psychological and pedagogical practice; application of the competence approach; humanization and democratization of education process; variety of forms and methods of students independent work; teacher's proficiency.

$\checkmark$ didactic and educational: giving students the possibility to choose disciplines and methods of study; avoiding stereotypic methods in conducting lessons, using problematic, interactive and scientific methods of teaching; standardizing of educational activity; structuring and prioritizing educational content; using principles of accessibility and didactics

$\checkmark$ psychological: holding sustainable interest in a chosen career; developing students' mental abilities, their awareness of intermediate and ultimate objectives of studying (close and long-term prospects), theoretical and practical significance of acquired knowledge, professional orientation of studying activity.

Prospects for further scientific research are to identify positive and negative impact on educational and cognitive activity of pedagogical university students; to explore the development of motivation for studying remotely; to research the specifics of forming motivation for studying and pursuing teaching career. 